\title{
Mathematical models and comparative analysis for rice irrigation crop water requirements: A case study of bida basin Niger State, Nigeria
}

\author{
Musa D. Shehu ${ }^{1}$, A. A. Ahmed And A. Abdulrahim $^{3}$ \\ ${ }^{1,3}$ Federal University of Technology, Minna, Niger State, Nigeria \\ ${ }^{2}$ Federal College of Education Technical Umunze, Anambra, Nigeria
}

Received: 13 June 2021, Accepted: 16 June 2021

Published online: 4 july 2021.

\begin{abstract}
In this paper, mathematical models for crop water Requirements (C.W.R) and the size of land for irrigation (S.L.I) were formulated. We fill the gap by considering the size of the irrigation land which was not considered by the Food and Agriculture Organization (F.A. O) in CROPWAT 8.0 software. The solutions of the models for Crop Water Requirement for Rice, and the size of land for irrigation (S.L.I) of the crops were obtained. The computational Method of solutions is carried out to get the effective results. The climatic data of the study area (Bida Basin) under which our research is based includes: Rainfall, Humidity, Sunshine hours, minimum and maximum Temperature, evapotranspiration were secondary data collected from Nigeria Metrological Society (NIMET). We compared the results of CROPWAT 8.0 software developed by the Food and Agriculture Organization (F.A. O) and our computational method so that we can arrive to a new finding and better results. The results for the computational method with the size of Land for irrigation shows that there is an increase in crop water need for the crops than the results of CROPWAT 8.0 software developed by Food and Agriculture Organization (F.A. O) in which the size of the land was not considered. We therefore recommended that an integral calculus can be used to estimate irregular shape of the size of the land if the land shape is not in a regular form before solutions is given for accuracy and effective results.
\end{abstract}

Keywords: Bida Basin, crop water coefficient, evapotranspiration.

\section{Introduction}

Bida Basin lies in the sedimentary terrain of the middle part of Nigeria. It has an area of coverage of about $27,000 \mathrm{~km}^{2}$. The area falls under middle climatic belt which is mainly tropical with average rainfall of about $1250 \mathrm{~m}$. We are therefore considering the crop water Requirement of Rice on aquifer of two lithological groups: unconfined and semi- confined aquifer in our selected study area. Cropwat 8.0 software is a software developed by Food and Agricultural Organisation (F.A.O), used to evaluate farmer's irrigations, irrigation practices and to estimate crop performance under both rainfall and irrigated condition. Our computational method is used as a tool to solve the models and obtain the solutions to get the effective results. The weakness of the cropwat software developed by Food and Agriculture Organization (F.A.O) is that the irrigation farmers do not know the size of the Land for which the results of the software is given, as the size of land for irrigation (S.L.I) is not consider by the Cropwat8.0 software, and we therefore fill the gap by considering the size of land for irrigation. Many irrigation farmers are faced with the challenges of what the crop water Requirements of irrigation crops would be before embarking on irrigation water planning. The aim of this research is to develop a mathematical model for crop water need problems and determine the exact amount of water Requirement for Rice crop by considering the size of the land and shape. Irrigated Agriculture in South Africa has not been profitable over the years. Despite the fact that it is the highest user of total consumptive water [1]. Its economic returns have not been impressive. A common 
procedure for estimating crop water use is to first determine the daily reference crop Evapo transpiration $\left(E T_{0}\right)$ and then multiply it by a specific crop coefficient $\left(K_{c}\right)$, as given by the Food and Agriculture Organisation [2]. [3] in determining the crop water requirements for Maize which is the major food crop in Abshege Woreda, Gurage zone in Ethiopia, they used the climatological records of Sunshine, maximum and minimum temperature, humidity and wind speed were used as secondary data. Penman Monteith method were used and crop water requirement was estimated using CROPWAT 8.0 the results shows that a Maize variety with a growing period of 140 days to maturity would requires $423 \mathrm{~mm}$ depth of water, while $101 \mathrm{~mm}$ of water would be required as supplementary irrigation. [4] came up with a quantitative analysis of hydraulic interaction process in stream - aquifer systems. [5] did a research on the crop water requirement for Agriculture in a typical River Basin of India. The results show the crop water requirements is much below the available rainfall and even available groundwater at various location of river basin, the crop water requirement is required to be increased by increasing the crop production with multiple crops and by using more Agriculture land for crop production. [6] develop and estimated aquifer hydraulic properties in Bida Basin Central Nigeria, using Empirical method. He determined aquifer properties such as hydraulic conductivity, porosity and effective porosity, and coefficient of uniformity.

\section{Mathematical model for crop water requirement}

\subsection{Metrological data}

To calculate this, the respective climatic data was collected from the Nigeria meteorological station. The data used for $\mathrm{ET}_{0}$ computation was the meteorological data obtained from the station; for instance, minimum and maximum temperatures (C), wind speed in km per day, the relative humidity (maximum and minimum, in \%) and the hours of sunshine, and the physical data such as altitude, latitude and longitude. The climatic records obtained were then adjusted into the format accepted by CROPWAT 8.0. The rainfall data collection was also obtained from the meteorological station. Rainfall records from a range of years (10-15) were collected to allow for calculation of Crop water need.

\subsection{Mathematical derivation of reference crop water need}

Considering an energy balance at the earth surface which equate all incoming and outgoing energy flux. The following governing equation is considered;

$$
R_{n}=H+\lambda E+G
$$

where, $R_{n}=$ energy flux density net incoming radiation $\left(w / m^{2}\right), \mathrm{H}=$ flux density of latent heat into the air $\left(w / m^{2}\right), \lambda E=$ flux density into the water body $\left(w / m^{2}\right), G=$ heat flux density into the water body $\left(w / m^{2}\right), \lambda=$ the latent heat of vaporization of water, $\mathrm{E}=$ the vapour flux density in $\mathrm{kg} / \mathrm{m}^{2} \mathrm{~s}$, The model is solved and we arrived at Pen-man Monteith equation given as,

$$
E T_{0}=\frac{0.408 \Delta\left(R_{n}-G\right)+\gamma \frac{900}{T a+273} u_{2}\left(e_{0}-e_{d}\right)}{\Delta+\gamma\left(1+0.34 u_{2}\right)}
$$

\subsection{Mathematical model for dual crop coefficient}

Considering crop coefficient, we let: $K_{c b t a b}=$ is the value for $\left(K_{c b}\right)_{\text {mid }}$ or $\left(K_{c b}\right)_{\text {end }}$

$$
K_{e}=K_{r}\left(K_{c}-K_{c b}\right)
$$

Simplifying the equation, we have

$$
K_{c}=K_{e}+K_{c b}
$$


where,

$$
K_{r}=1
$$

$K_{e}=$ soil evaporation coefficient, $K_{c b}=$ Basal crop coefficient, $k_{c}=$ crop coefficient value of $K_{c}$ following rain or irrigation, $K_{r}=$ Dimensionless evaporation reduction coefficient dependent on the cumulative depth of water depleted (evaporated) from the top soil.

\subsection{Mathematical formulation of irrigated area of land $\left(A_{i}\right)$}

We consider the Area of the irrigated land as a rectangular surface; Let $L=$ length of the farm, B = Breadth of the farm, 1 $=$ length of the spacing on the farm land, $\mathrm{b}=$ breadth of the spacing on the farm land, The spacing area of the farm land is considered to be;

$$
l b=\left(\frac{L B}{P_{n}}\right) N
$$

where, $P_{n}=$ number of plants on the farm land, $\mathrm{N}=$ number of seeds per stand.

$$
A_{i}=l b P_{n}-(L b+l B+l b I)
$$

Where; $A_{i}=$ irrigated area of land.

$$
E T_{c w n}=E T_{0} \times K_{c} \times A_{i}
$$

Where, $E T_{c w n}=$ crop water need, $E T_{0}=$ reference crop evapotranspiration, $K_{c}=$ crop water coefficient, $A_{i}=$ crop irrigated area, Combining equation (2), (4) and (7), the crop water need equation becomes;

$$
E T_{c w n}=\left(\frac{0.408 \Delta\left(R_{n}-G\right)+\gamma_{\frac{900}{T a+273}} u_{2}\left(e_{s}-e_{a}\right)}{\Delta+\gamma\left(1+0.34 u_{2}\right)}\right) \times\left(K_{c b}+K_{e}\right) \times\left(l b P_{n}-(L b+l B+l b I)\right)
$$

\section{Result and Discussion}

Table 1. shows the comparison of Cropwat 8.0 software and our Computation method for Rice Crops.

\begin{tabular}{|l|l|l|l|l|l|l|l|l|}
\hline Month & $\begin{array}{l}\mathrm{ET}_{0} \\
\text { (F.A.O) }\end{array}$ & $\mathrm{ET}_{0}$ & $\begin{array}{l}\mathrm{K}_{c} \\
(\mathrm{FAO})\end{array}$ & $\mathrm{K}_{c}$ & $\begin{array}{l}\mathrm{ET}_{c w n} \\
(\mathrm{FAO})\end{array}$ & $\begin{array}{l}\mathrm{ET}_{c w n} \\
\mathrm{Mm}\end{array}$ & $\begin{array}{l}\text { Ai } \\
\text { (F.A.O) }\end{array}$ & $\begin{array}{l}\mathrm{A}_{i} \\
\text { Hectares }\end{array}$ \\
\hline November & 4.44 & 4.92 & 4.27 & 3.93 & 1689 & 9571 & Nill & 569 \\
\hline December & 4.45 & 4.32 & 3.3 & 3.12 & 1515 & 6721 & Nill & 569 \\
\hline January & 4.42 & 4.25 & 4.4 & 3.67 & 1521 & 1826 & Nill & 569 \\
\hline February & 4.73 & 4.21 & 3.24 & 3.84 & 1431 & 1646 & Nill & 569 \\
\hline March & 5.17 & 4.08 & 5.2 & 1.29 & 7560 & 627 & Nill & 569 \\
\hline
\end{tabular}

Table 1: Comparison of Cropwat 8.0 software and our Method.

Table 1. shows the comparison results analysis of the outcome of Cropwat 8.0 Software developed by F.A.O and our computational method for Rice irrigation crop water needs, reference evapotranspiration $\left(\mathrm{ET}_{0}\right)$ and crop coefficient $(\mathrm{Kc})$ in Bida Basin Irrigation Sites. It is observed from the table that, reference evapotranspiration $\left(\mathrm{ET}_{0}\right)$ results in computational method is decreasing as the dry season is biting harder, while it alternates in Cropwat 8.0 Software results developed by F.A.O., the crop coefficient $\left(\mathrm{K}_{c}\right)$ results in our computational method maintains the same behaviour except in March where we have $1.29\left(\mathrm{~K}_{c}\right)$ this is due to harvesting period which is when crops need little or no water, compare to Cropwat 
8.0 Software developed by F.A.O which is $5.2\left(\mathrm{~K}_{c}\right)$ in March. The crop water needs in the our method is higher than the Cropwat 8.0 Software developed by F.A.O, this is due to the fact that the quantity of crop water need in each month of the dry season is known to the farmers within available land size of 569 hectare.

\section{Conclusion}

The Penman Monteith Mathematical model for the crop water need and Mathematical model for the size of land for irrigation were solved and the results obtained are compared with CROPWAT 8.0 software results, the climatic data of the study area (Bida Basin) under which our research is based include: Rainfall, Humidity, minimum and maximum Temperature, evapotranspiration were collected from NIMET and used for the both CROPWAT 8.0 software and our computational method, so that comparative analysis can be made from the two methods. Our computational method results show that crop water Requirement for crop can better be estimated if the size of the land for irrigation is considered.

\section{Competing interests}

The authors declare that they have no competing interests.

\section{Authors' contributions}

All authors have contributed to all parts of the article. All authors read and approved the final manuscript.

\section{References}

[1] M.N. Nkodo, F.C. Van zyl, H. Keuris, \& B. Schreine, Proposed National Water resources Straregy 2 (NWRS) Summary Cape Town. Department of Water Affair, South Africa 3 (2012) 9.

[2] Food and Agriculture of the united Nation state of the Rome world's https//www.faoorg/011/1035e00htm (2010).

[3] A.Y. Solomon, M. Girma, \& M. Mengistu, Determination of Crop Water Requirements for maize in Abshege Wreda, Gurage Zone, Eithopia, Journal of earth science and climatic Change 9 (2018) 2157.

[4] W.Z. Wenken, W. Dai, \& Y. Zhao, A quantitative Analysis of Hydraulic Interaction Process in Stream Aquifer System. Journal of science education and Agronomy Journal, 3 (2016) 426.

[5] P. Rijwana, A Study on the Crop Water Requirement for Agriculture in Typical River Basin of India, International Journal of Water Research; 2 (2014) 67.

[6] I. N. Abdullahi, Estimating Aquifer Hydraulic properties in Bida Basin, Central Nigeria using Empirical Methods, Journal of Earth Science Research, 2 (2013) 1. 